\title{
Expression of exogenous DNA in the gonads of chimaeric chicken embryos produced by transfer of primordial germ cells transfected in vitro and subsequent fate of the introduced DNA
}

\author{
M. Naito ${ }^{1}$, M. Sakurai ${ }^{2}$ and T. Kuwana ${ }^{3}$ \\ ${ }^{1}$ National Institute of Animal Industry, Tsukuba Norindanchi PO Box 5, Ibaraki 305-0901, Japan; ${ }^{2}$ National \\ Institute of Animal Health, 3-1-1 Kannondai, Tsukuba, Ibaraki 305-0856, Japan; and ${ }^{3}$ National Institute for \\ Minamata Disease, Minamata, Kumamoto 867-0008, Japan
}

\begin{abstract}
The expression and fate of exogenous DNA (lacZ gene), introduced into the gonads of chimaeric embryos and chickens that had been produced by transfer of primordial germ cells (PGCs) transfected in vitro, were examined. PGCs obtained from embryonic blood were transfected in vitro by lipofection and transferred to the partially sterilized recipient embryos. Expression of the lac $Z$ gene was observed in the gonads of chimaeric embryos incubated for 3 days after the PGC injection (71.2\%, 37/52). Introduction of the lacZ gene into the gonads of chimaeric embryos was confirmed by PCR analysis. The percentage of embryos with gonads positive for the lac $Z$ gene was 95\% (38/40) after 3 days of incubation after the PGC injection. The lacZ gene, however, appeared to persist episomally but was gradually lost during embryonic development. After 17 days of incubation after the PGC injection, the lacZ gene was detected in only $14.3 \%(3 / 21)$ of the embryos examined. Although the lac $Z$ gene was detected in the gonads of two hatched chicks (11.1\%), it was not detected in the gonads of chimaeric chickens at sexual maturity. Offspring derived from the lipofected PGCs were obtained from the chimaeric chickens at frequencies of $12.1-69.9 \%$ in males and $71.6-97.6 \%$ in females. The technique developed in the present work could be used to test the expression of exogenous DNA in the gonads of early chicken embryos and should facilitate the production of transgenic chickens.
\end{abstract}

\section{Introduction}

The production of transgenic chickens is useful for biological research as well as for the genetic improvement of poultry. Although many transgenic mammals have been produced successfully (Wall, 1996), production of transgenic chickens still faces considerable difficulties because of the yolk-laden structure of the ovum and the unique reproductive system of birds (Perry and Sang, 1993; Sang, 1994; Naito, 1996, 1997). Various attempts have been made to produce transgenic chickens; however, non-retroviral methods are preferable for applying the transgenic techniques to practical poultry breeding programmes. DNA transfer into chickens has been achieved by microinjection into the germinal disc of the fertilized ovum (Naito et al, 1994a), transfection of the blastoderm (stage X, Eyal-Giladi and Kochav, 1976) in ovo (Kopchick et al., 1991) and ballistic transfection of primordial germ cells (PGCs) in ovo (Li ef al, 1995). However, the DNA introduced into chickens persisted episomally and disappeared during the life of the chickens. Integration of exogenous DNA into the chromosomes of chickens has recently been achieved by the microinjection method (Love et al., 1994). Although the efficiency of germline transmission and chromosomal

Received 21 August 1997 integration of the introduced DNA are reasonable, the number of fertilized ova that can be manipulated in each experimental session by this method is limited.

For modifying a specific location of the chicken genome, it is necessary to establish a culture of stem cells maintained in vitro. However, to date, it has not been possible to establish stem cells that give rise to viable offspring by way of germline chimaeric chickens. Blastodermal cells (stage X, Eyal-Giladi and Kochav, 1976) or PGCs cultured for only a few days in vitro have been incorporated into the germline of recipient embryos (Chang, 1995; Etches et al., 1996; Pain et al., 1996). Transfected blastodermal cells were injected into recipient embryos at the same developmental stage and the expression of an introduced lac $Z$ gene was observed after incubation for $2-3$ days (Brazolot et al., 1991; Fraser et al., 1993); but it was unclear whether the successfully transfected blastodermal cells could enter the germline of recipient embryos.

We have been trying to develop a technique for gene transfer into chickens by way of PGCs, because PGCs are progenitor cells of ova or spermatozoa and should ensure the transmission of genetic modifications to the next generation. Since avian PGCs circulate temporarily in the bloodstream before migrating into the germinal ridges (Kuwana, 1993), PGCs in the blood circulation were transfected in vivo by lipofection (Watanabe et al., 1994). The average number of 
PGCs positive for the lac $Z$ gene per embryo after 2-3 days of the treatment was 2.1 in 29 embryos analysed and the efficiency of successful transfection of PGCs was $0.1-1.4 \%$. For precise manipulation of PGCs in vitro, PGCs were collected from embryonic blood and then transferred into the bloodstream of recipient embryos of a different breed to produce germline chimaeric chickens (Tajima et al., 1993). Germline chimaeric chickens with a high transmission rate (77.3-96.8\%) of donor-derived gametes have been produced by increasing the number of donor PGCs and by partially sterilizing the recipient embryos (Naito et al., 1994b; 1998). Also, PGCs obtained from embryonic blood have been frozen successfully in liquid nitrogen $\left(-196^{\circ} \mathrm{C}\right)$, and subsequently produced viable offspring by way of germline chimaeric chickens (Naito et al., 1994c). Thus, we are close to establishing an efficient system for giving rise to viable offspring from transfected PGCs by way of germline chimaeric chickens.

The present study was carried out to examine the expression of exogenous DNA in the gonads of chimaeric embryos produced by transfer of PGCs transfected in vitro and to determine the subsequent fate of the introduced DNA in the gonads of chimaeric embryos and hatched chickens.

\section{Materials and Methods}

\section{Preparation of fertilized eggs}

Fertilized eggs of White Leghorn and Barred Plymouth Rock chickens were obtained, by artificial insemination, from the genetic stocks maintained at the National Institute of Animal Industry.

\section{Preparation of donor PGCS}

Fertilized White Leghorn eggs were incubated at $38^{\circ} \mathrm{C}$, relative humidity $60 \%$, in air for about $53 \mathrm{~h}$ in a forced air incubator (P-008; Showa Incubator Laboratory, Yono-shi, Saitama) and blood was collected from the dorsal aorta of embryos at stages 13-15 (Hamburger and Hamilton, 1951) using a fine glass micropipette. PGCs were concentrated by a Ficoll-density gradient centrifugation method (Yasuda et al, 1992) and the PGC-rich fraction (PGCs constituted $60 \%$ of the cells in this fraction) was dispersed in $500 \mu$ l culture medium (Dulbecco's Modified Eagle's Medium (DMEM; Gibco BRL Life Technologies, NY) supplemented with 10\% fetal bovine serum (Flow Laboratories, McLean, VA)).

\section{Transfection of PGCs in vitro}

The plasmid DNA used for the present experiment was $\mathrm{pAcZ}$, which contains Escherichia coli lacZ gene under the control of the chicken $\beta$-actin gene promoter (Naito et al., 1994a). Transfection of PGCs was carried out by lipofection using a cationic lipid, $N$-[1-(2,3-dioleoyloxy)propyl]-N,N,Ntrimethylammoniummethylsulfate (DOTAP, No. 1781995; Boehringer Mannheim Biochemica, Mannheim). Four microlitres of DOTAP solution ( $1 \mu \mathrm{g} \mu \mathrm{l}^{-1}$ ) were first diluted with $20 \mu \mathrm{l} \mathrm{HBS}\left(20 \mathrm{mmol} \mathrm{Hepes} 1^{-1}, 150 \mathrm{mmol} \mathrm{NaCl} l^{-1}, \mathrm{pH} \mathrm{7.4)}\right.$ in a $6 \mathrm{ml}$ polystyrene culture tube (code 8567; Stockwell
Scientific, Wallnut, CA), mixed with $3.4 \mu \mathrm{l}$ of plasmid DNA at

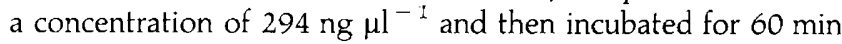
at room temperature. The collected donor PGCs were dispersed in $500 \mu \mathrm{l}$ culture medium and then added to the DOTAP:DNA solution. The cap of the culture cube was tightly sealed and incubated for $5 \mathrm{~h}$ at $38^{\circ} \mathrm{C}$, with no humidified condition, in air. The PGCs were then washed with culture medium, dispersed in $100 \mu \mathrm{l}$ fresh culture medium and placed in a plastic dish (code 3001; Falcon, Becton Dickerson Co., Lincoln Park, NJ). Control PGCs were lipofected in a similar manner but without the pAcZ.

Closed, circular-form plasmid DNA was used when the lac $Z$ gene expression was examined in the gonads of embryos incubated for 3 days after the PGC injection, and linear form plasmid DNA, digested with BamHI, was used when the fate of the lac $Z$ gene was examined in the gonads of chimaeric embryos, at various days of incubation after the PGC injection, and in the gonads of the hatched chickens.

\section{Preparation of recipient embryos and PGC transfer}

Recipient embryos were cultured in host egg shells, as described by Naito et al. (1990), to allow precise manipulation. Fertilized eggs of Barred Plymouth Rock recipient embryos (stage X, Eyal-Giladi and Kochav, 1976) were broken and the embryos (yolks) were transferred to small host egg shells. The reconstituted eggs were incubated at $38^{\circ} \mathrm{C}$, relative humidity $60 \%$, in air for about $53 \mathrm{~h}$. When the embryos had reached stages 14-15 (Hamburger and Hamilton, 1951), blood $(4-10 \mu \mathrm{l})$ was drawn, as much as possible from the dorsal aorta (to eliminate the endogenous PGCs), using a fine glass micropipette. The embryos were then incubated for a further $2-4 \mathrm{~h}$ before the PGC injection.

Three hundred, lipofected PGCs were picked up by a fine glass micropipette under a light microscope (total volume was about $I \mu \mathrm{l}$ ). The PGCs were injected into the bloodstream of recipient embryos via the dorsal aorta. The manipulated embryos were then transferred to large host egg shells and incubated at $38^{\circ} \mathrm{C}$, relative humidity $60 \%$, in air for 3-17 days, or until hatching (Perry, 1988; Naito et al., 1990).

\section{Detection of the lacZ gene expression in the gonads of chimaeric embryos}

Embryos cultured for 3 days after injection of PGCs were removed from the yolk, fixed with $1 \%(\mathrm{v} / \mathrm{v})$ glutaraldehyde in DPBS(-) (Dubecco's PBS without $\mathrm{Ca}^{2+}$ and $\mathrm{Mg}^{2+}$, No. 21300-025; Gibco BRL Life Technologies, New York) for $30 \mathrm{~min}$ and then washed three times with gentle shaking in DPBS $(-)$. The embryos were then incubated for $2 \mathrm{~h}$ at $37^{\circ} \mathrm{C}$ in a staining solution $(\mathrm{pH} 7.4)$ containing $0.05 \%(\mathrm{v} / \mathrm{v}) 5$-bromo4-chloro-3-indolyl- $\beta$-D-galactopyranoside (X-gal, Nakarai Tesque, Tokyo), $1 \mathrm{mmol} \mathrm{MgCl}_{2} \mathrm{l}^{-1}, 0.1 \%(\mathrm{v} / \mathrm{v})$ Triton $\mathrm{X}$, $3 \mathrm{mmol}$ potassium ferrocyanide $\mathrm{I}^{-1}$ and $3 \mathrm{mmol}$ potassium ferricyanide $\mathrm{I}^{-1}$ in DPBS( - ) (Naito ef al., 1991).

\section{Defection of the lacZ gene in the gonads of chimaeric embryos and chickens}

Gonads were obtained from the embryos cultured for 3-19 days after injection of lipofected PGCs and homogenized. 
Spermatozoa of the male germline chimaeric chickens and blood of donor-derived offspring from the female germline chimaeric chickens (owing to the difficulty of collecting ova from live female chickens) were obtained and washed with DPBS $(-)$. DNA was then extracted from the gonadal cells, spermatozoa and blood cells using a DNA Extraction Kit (SepaGene $e^{(i x}$, Sanko Junyaku, Tokyo). The extracted DNA was dissolved in TE buffer (10 mmol Tris- $\mathrm{HCl} 1^{-1}, 0.25 \mathrm{mmol}$ EDTA $\mathrm{I}^{-1}, \mathrm{pH} \mathrm{8.0)}$ and PCR analysis was then performed on 100 ng DNA samples to detect the lac $Z$ gene.

The PCR was carried out using a programmable thermal controller (Model 480, Perkin Elmer, Norwalk, CT). The PCR reactions were performed in $50 \mu \mathrm{l}$ of $10 \mathrm{mmol}$ Tris $-\mathrm{HCl} \mathrm{l^{-1 }}$, $1.5 \mathrm{mmol} \mathrm{MgCl}_{2} \mathrm{1}^{-1}, 50 \mathrm{mmol} \mathrm{KCl}^{-1}, 0.1 \mathrm{mg} \mathrm{ml}^{-1}$ gelatin, $200 \mu \mathrm{mol} \mathrm{dNTPs} \mathrm{l}^{-1}, 0.5 \mu \mathrm{mol}$ primers $\mathrm{l}^{-1}$ and $2.5 \mathrm{U}$ Taq polymerase (No. R001B; Takara, Tokyo). The sequences of the primers for detecting the lac $Z$ gene were: $5^{\prime}$-AGATGCACGGT

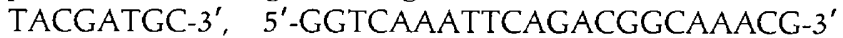
(Love et al., 1994). For internal control, a sequence of the endogenous GAPDH gene was amplified using the primers: 5'-TGTGACTTCAATGGTGACA-3', 5'-CAGATCAGTTTC TATCAGC-3' (Love et al., 1994). After an initial denaturation step of $94^{\circ} \mathrm{C}$ for $2 \mathrm{~min}, 40$ cycles of amplification were performed; DNA was denatured at $94^{\circ} \mathrm{C}$ for $30 \mathrm{~s}$, annealed at $55^{\circ} \mathrm{C}$ for $30 \mathrm{~s}$ and extended at $72^{\circ} \mathrm{C}$ for $30 \mathrm{~s}$. The reactions were then incubated at $72^{\circ} \mathrm{C}$ for $5 \mathrm{~min}$. PCR products were separated on a $2 \%$ agarose gel and the bands were visualized under UV light after ethidium bromide staining.

\section{Frequency of germline transmission of donor PGCs}

White Leghorn are homozygous dominant $(I / I)$ and Barred Plymouth Rock are homozygous recessive $(i / i)$ for the autosomal pigment inhibitor gene. Chimaeric chickens that survived to sexual maturity were mated with Barred Plymouth Rock by artificial insemination and the feather colour of their offspring was examined. Since PGCs were transferred from White Leghorn to Barred Plymouth Rock, white chicks $(I / i)$ from chimaeric chickens indicated that they were derived from the transferred White Leghorn PGCs and black chicks $(i / i)$ indicated that they were derived from the endogenous Barred Plymouth Rock PGCs.

\section{Results}

\section{Morphology of $P G C S$ after lipofection}

Freshly collected PGCs and lipofection-treated PGCs are shown (Fig. 1). No apparent difference was observed in morphology before and after lipofection.

\section{Expression of the lacZ gene in the embryonic gonads}

The expression of the lac $Z$ gene in the gonads of embryos incubated for 3 days after the injection of PGCs transfected in vitro is shown (Fig. 2). Many, intensely blue-stained cells were observed in the right and left gonads (Fig. 2a) or mainly in the left gonad (Fig. 2b) of the chimaeric embryos. The number of cells stained blue per embryonic gonad varied from a few to more than 50 (13.7 on average), and many of the blue spots consisted of several cells. Cells expressing the lac $Z$ gene were distributed throughout the gonads of the chimaeric embryos. No gonadal staining was observed in the control embryos produced by the transfer of PGCs lipofected in vitro without pAcZ. Of 52 embryos examined, 37 (71.2\%) embryos showed the expression of the lac $Z$ gene in the right or left gonads and $15(28.8 \%)$ embryos showed no expression of the lac $Z$ gene.

\section{Presence of the lac $Z$ gene in the gonads of chimaeric embryos}

DNA samples from the gonads of chimaeric embryos were analysed for the presence of the lacZ gene by PCR (Fig. 3). The number of embryos with gonads that expressed the lac $Z$ gene out of the 209 manipulated embryos are shown (Table 1). The lac $Z$ gene was detected in the majority of embryos examined after 3 days of incubation after the injection of the lipofected PGCs (total incubation time 5.5 days). However, the lac Z gene was detected in only a small proportion of the embryos examined after 17 days of incubation after the PGC injection (19.5 day incubated embryo). Although the percentages of embryos with gonads positive for the lac $Z$ gene decreased gradually during development, the lac $Z$ gene was detected in the gonads of two hatched chicks $(11.1 \%, 2 / 18)$.

\section{Presence of the lac $Z$ gene in the germline of chimaeric chickens}

DNA was extracted from the sperm samples of eight male germline chimaeric chickens and from the blood samples of 216 donor-derived offspring from three female germline chimaeric chickens, and analysed for the presence of the lac $Z$ gene. In none of the DNA samples was the lac $Z$ gene detected by PCR analysis.

\section{Germline chimaerism obtained from progeny test}

One hundred and seven White Leghorn embryos were injected with Barred Plymouth Rock PGCs transfected in vitro and $36(33.6 \%)$ chicks were obtained. Male and female chickens that reached maturity and were tested were all germline chimaeras (Table 2). The proportion of germline transmission of donor PGCs was $12.1-69.9 \%$ (35.3\% on average) in eight male chimaeric chickens and $71.6-97.6 \%(86.9 \%$ on average $)$ in three female chimaeric chickens. Germline chimaerism of the male and female chimaeric chickens did not change markedly with increasing age.

\section{Discussion}

In the study described here, exogenous DNA (the lac $Z$ gene) was successfully introduced into the gonads of chimaeric embryos by transferring PGCs that had been obtained from embryonic blood and transfected in vitro by lipofection. The expression of the lac $Z$ gene was observed in the gonads of embryos incubated for 3 days after the PGC injection. In addition, the presence of the lac $Z$ gene in the gonads of 

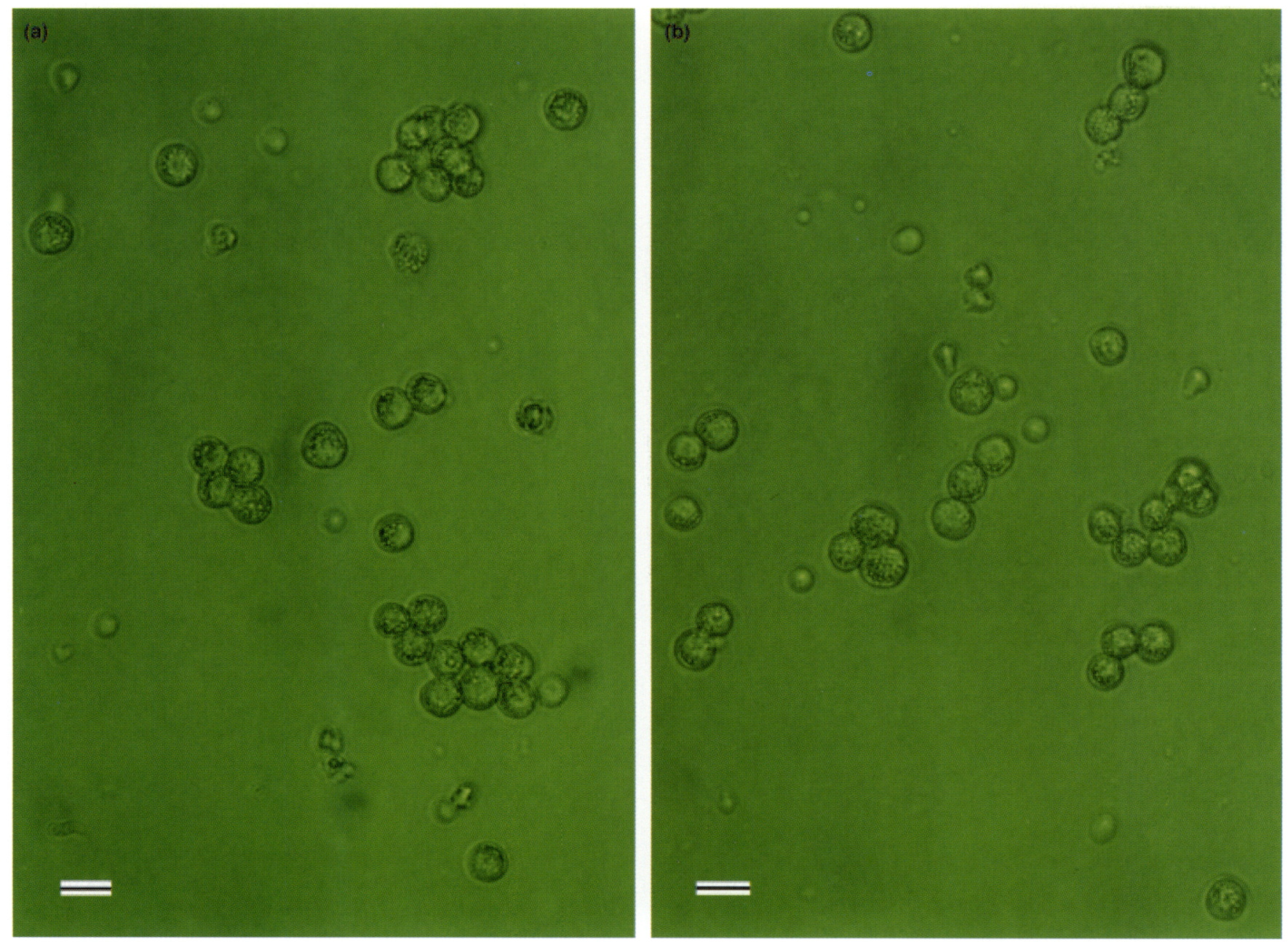

Fig. 1. Chicken primordial germ cells (a) before and (b) after the lipofection treatment. Blood was collected from embryos at stages $13-15$ and primordial germ cells (large cells with eccentrically placed nuclei and a considerable number of lipids in the cytoplasm) were concentrated by Ficoll-density gradient centrifugation. The small round cells are erythrocytes. Scale bar represents $20 \mu \mathrm{m}$.

chimaeric embryos was confirmed by PCR analysis. The percentages of embryos positive for the lac $Z$ gene, after 3 days of incubation after the PGC injection, was very high (95\%); however, the lac $Z$ gene was detected in only $14.3 \%$ of embryos examined after 17 days of incubation after the PGC injection. Nevertheless, the lac $Z$ gene was still detectable in the gonads until the chimaeric embryos had hatched. However, upon sexual maturation, the lac $Z$ gene was not detected in the gonads of chimaeric chickens, and was not transmitted to the next generation. Similar results have been obtained in Xenopus, in that DNA injected into the cytoplasm usually remains extrachromosomal during early cleavage stages, is replicated up to the blastula stage and is then gradually lost (Bendig, 1981; Rusconi and Schaffner, 1981). In the present experiment, the lac $\mathrm{Z}$ gene introduced into the embryonic gonads appears to be present episomally in the PGCs or germ cells, and is gradually lost during embryonic development.

As assessed by PCR, the lac $Z$ gene was present in $95 \%$ of the embryos examined after 3 days of incubation after the PGC injection, while expression of the lac $Z$ gene was observed in $71.2 \%$ of embryos examined the same developmental stage. The difference in the frequency of presence and expression of the lac $Z$ gene suggests that not all the lac $Z$ genes introduced into the embryonic gonads are expressed. In some of the successfully transfected PGCs, the lac $Z$ gene may remain in the cytoplasm and therefore shows no expression. The average number of lac $Z$ gene-positive cells in the gonads was 13.7 per embryo in the currently reported experiment and was much higher than that produced by in vivo transfection of PGCs $\{2.1$ cells per embryo, Watanabe et al., 1994). Thus, in vitro manipulation used in the present experiment was much more efficient than in vivo manipulation for the transfection of PGCs.

Germline transmission of exogenous DNA into the G1 generation has been achieved using PGCs (Vick and Simkiss, 1993). PGCs obtained from the germinal crescent region or from the blood of early-stage embryos were transfected with defective retroviruses and transferred to the recipient embryos to form chimaeras that grew to sexual maturity and produced offspring. Exogenous DNA was detected in some of the GI offspring, as well as in the spermatozoa of the GO chimaeric chickens. In the work described here, a similar procedure was applied to produce transgenic chickens, but germline transmission of exogenous DNA was not achieved. This was probably due to the low efficiency of chromosomal integration of 

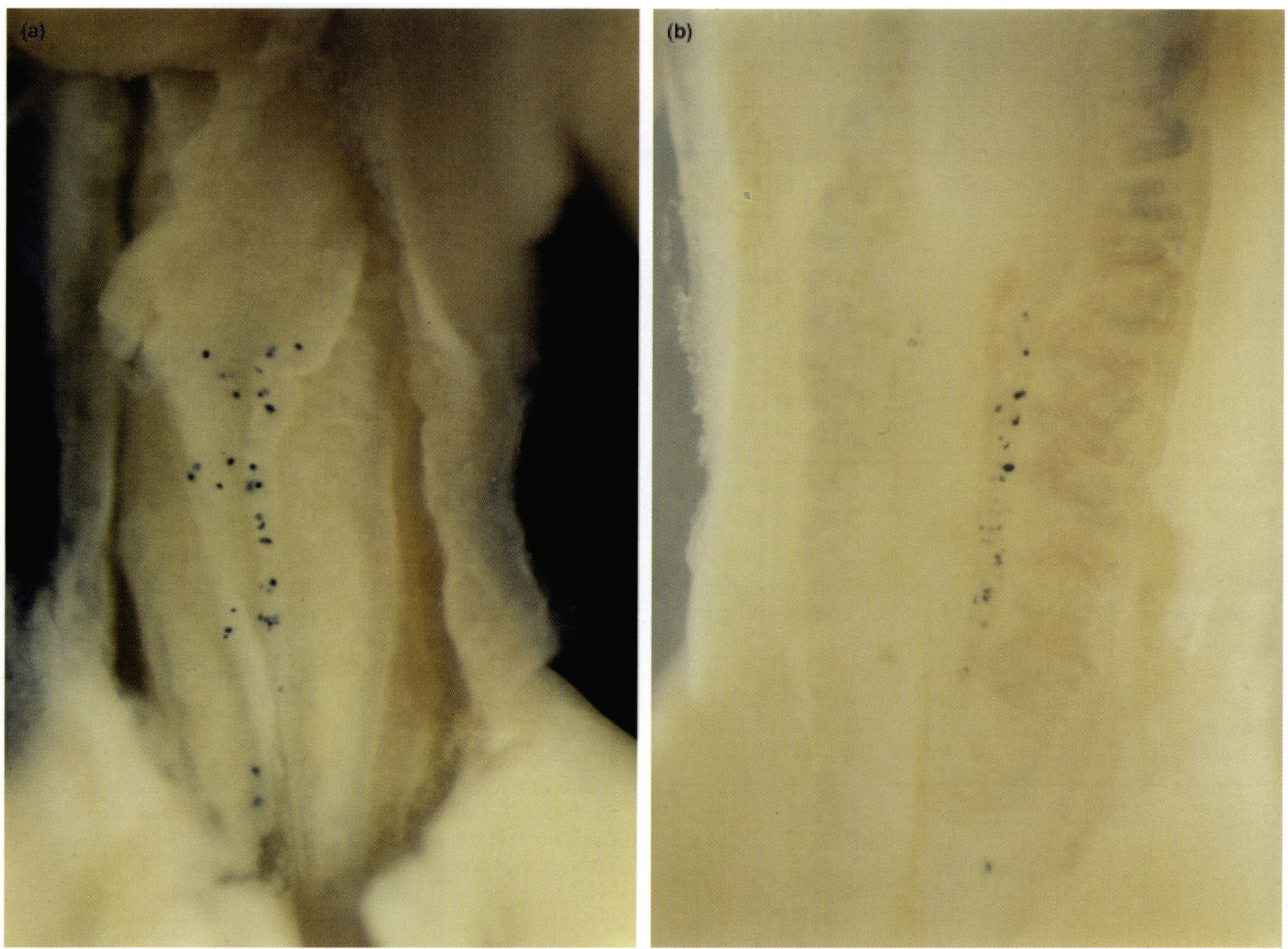

Fig. 2. Expression of the lac $Z$ gene in the gonads of chimaeric chicken embryos 3 days after the injection of primordial germ cells transfected in vitro. Cells stained blue indicate the expression of the lac $Z$ gene and are scattered in the developing (a) right and left gonads or (b) mainly in the left gonad of chimaeric embryos.

\section{$\begin{array}{lllllllllllllllllllll}1 & 2 & 3 & 4 & 5 & 6 & 7 & 8 & 9 & 10 & 11 & 12 & 13 & 14 & 15 & 16 & 17 & 18 & 19 & 20 & 21\end{array}$}

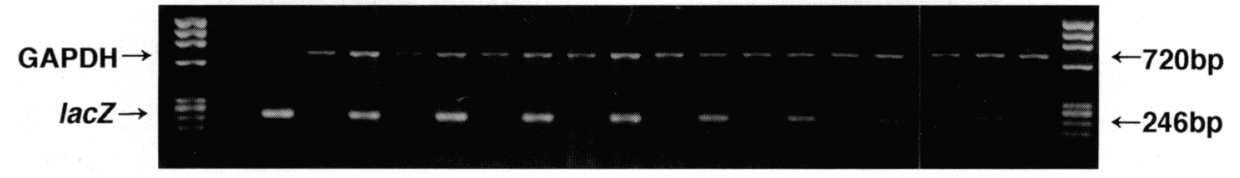

Fig. 3. Analysis of the chimaeric chicken embryos produced by transfer of primordial germ cells transfected in vitro with the plasmid DNA pAcZ. DNA was extracted from the gonads of chimaeric embryos and analysed by PCR to detect the lac $Z$ gene of the plasmid and the endogenous GAPDH gene for internal control. Lanes 1 and 21: molecular size marker (PhiX174 DNA digested with Hae III restriction enzyme); lane 2: negative control (water); lane 3: positive control ( $\mathrm{pAcZ}$ ); lane 4: control DNA from intact chicken embryonic gonads. Lanes 5-20 show positive and negative embryos for the lac $Z$ gene at various days after the primordial germ cell injection (lanes 5 and 6: 3 days; lanes 7 and 8: 4 days; lanes 9 and 10: 5 days; lanes 11 and 12: 7 days; lanes 13 and 14: 10 days; lanes 15 and 16: 13 days; lanes 17 and 18: 17 days; lanes 19 and 20: chicks at hatch).

exogenous DNA into PGCs by the lipofection method compared with the retrovirus vector method. All methods of transfection of isolated cells produce more transient than stable transfections. Although the construct was not found in the germline of mature birds, stable transfection may occur, but the frequency may be so low that a greater number of birds would have to be examined before it would be detectable in the germline.

The PGCs lipofected in vitro were morphologically normal, successfully migrated into the germinal ridges and differentiated into ova or spermatozoa in the gonads of the chimaeric embryos and chickens. These gametes were functional and 
Table 1. Presence of the lac $Z$ gene introduced into the gonads of chimaeric chicken embryos by transfer of primordial germ cells transfected in vitro as determined by PCR

\begin{tabular}{lcc}
\hline $\begin{array}{l}\text { Days of } \\
\text { incubation after }\end{array}$ & Number of & Number of embryos \\
injection* & embryos & positive for lac \\
& manipulated & $(\%)$
\end{tabular}

$\begin{array}{rrr}3(5.5) & 40 & 38(95.0) \\ 4(6.5) & 22 & 15(68.2) \\ 5(7.5) & 12 & 8(66.7) \\ 7(9.5) & 23 & 8(34.8) \\ 10(12.5) & 21 & 4(19.0) \\ 13(15.5) & 52 & 9(17.3) \\ 17(19.5) & 21 & 3(14.3) \\ \text { Hatch }(21.0) & 18 & 2(11.1)\end{array}$

*Days of incubation after the start of incubation from laid egg stage are shown in parentheses.

Table 2. Progeny test of chimaeric chickens produced by transfer to Barred Plymouth Rock of White Loghorn primordial germ cells transfected in vitro

\begin{tabular}{|c|c|c|c|c|}
\hline $\begin{array}{l}\text { Chimaera } \\
\text { ID number }\end{array}$ & $\begin{array}{l}\text { Number } \\
\text { of chicks } \\
\text { hatched }\end{array}$ & $\begin{array}{l}\text { Number } \\
\text { of white } \\
\text { chicks* }\end{array}$ & $\begin{array}{c}\text { Number } \\
\text { of black } \\
\text { chicks }\end{array}$ & $\begin{array}{c}\text { White } \\
\text { chicks* } \\
(\%)\end{array}$ \\
\hline$\widehat{S} 1$ & 359 & 89 & 270 & 24.8 \\
\hline 32 & 230 & 114 & 116 & 49.6 \\
\hline 33 & 223 & 27 & 196 & 12.1 \\
\hline 34 & 233 & 58 & 175 & 24.9 \\
\hline 35 & 155 & 96 & 59 & 61.9 \\
\hline 36 & 166 & 116 & 50 & 69.9 \\
\hline 37 & 256 & 38 & 218 & 14.8 \\
\hline 38 & 267 & 64 & 203 & 24.0 \\
\hline 71 & 140 & 128 & 12 & 91.4 \\
\hline 92 & 67 & 48 & 19 & 71.6 \\
\hline 93 & 41 & 40 & 1 & 97.6 \\
\hline
\end{tabular}

*Donor-derived offspring.

gave rise to viable offspring, although the majority of the DNA introduced into the gonads of chimaeric embryos disappeared during their embryonic development. The average proportion of donor-derived offspring from the germline chimaeric chickens produced by transfer of PGCs lipofected in vitro were $35.3 \%$ in males and $86.9 \%$ in females. The proportion of donor-derived offspring from the male chimaeric chickens was lower than that in our previous experiments $(80.8 \%$, Naito et al., 1994b) in which germline chimaeric chickens were produced by transfer of freshly collected, non-transfected PGCs. However, the frequency of donor-derived offspring from the female chimaeric chickens showed only a slight decrease compared with our previous result $195.8 \%$, Naito et al., 1994b). Thus, the lipofection treatment of PGCs used in the present experiment only slightly affected the migration of PGCs into the germinal ridges and the subsequent development and differentiation into gametes in the chimaeric embryos and chickens.
PGCs in recipient embryos can be compromised by $\gamma$-radiation (Carsience et al., 1993), or exposure to busulphan to obtain a high transmission rate of donor-derived gametes from germline chimaeric chickens (Aige-Gil and Simkiss, 1991). In the currently reported experiment, blood was drawn as much as possible from the recipient embryos, since PGCs circulate in the bloodstream (Naito et al., 1994b). This alternative method was effective for decreasing the number of PGCs in the recipient embryos, and the donor-derived offspring from the chimaeric chickens were efficiently produced.

The technique described in the present study could be used to test the expression of exogenous DNA in the gonads of early chicken embryos. It may, however, be difficult to produce transgenic chickens routinely at the present level of transfection efficiency for PGCs and because of the restrictions on the number of PGCs that can be manipulated at one time (about 3000 PGCs). Integration efficiency of exogenous DNA into the host chromosome must be increased and the PGCs integrated with exogenous DNA must be selected and proliferated by culture in vitro to produce transgenic chickens by way of PGCs. Then, transgenic chickens could be produced efficiently. In addition, it would be possible to manipulate specific locations of the avian genome by homologous recombination using stem cells maintained in vitro, such as embryonic germ cells derived from PGCs.

The authors are grateful to the staff of the Poultry Management Section of the National Institute of Animal Industry for taking care of the birds. This study was supported by the Special Coordination Funds for Promoting Science and Technology from the Science and Technology Agency of the Japanese Government.

\section{References}

Aige-Gil V and Simkiss K (1991) Sterilising embryos for transgenic chimaeras British Poultry Science 32 427-438

Bendig MM (1981) Persistence and expression of histone genes injected into Xenopus eggs in early development Nature 292 65-67

Brazolot CL, Petitte JN, Etches RJ and Verrinder Gibbins AM (1991) Efficient transfection of chicken cells by lipofection, and introduction of transfected blastodermal cells into chick embryos Molecular Reproduction and Development 30 304-312

Carsience RS, Clark ME, Verrinder Gibbins AM and Etches RJ (1993) Germline chimeric chickens from dispersed donor blastodermal cells and compromised recipient embryos Development $117669-675$

Chang IK, Yoshiki A, Kusakabe M, Tajima A, Chikamune T, Naito M and Ohno T (1995) Germ line chimera produced by transfer of cultured chick primordial germ cells Cell Biology International 19 569-576

Etches RJ, Clark ME, Toner A, Liu G and Verrinder Gibbins AM (1996) Contributions to somatic and germline lineages of chicken blastodermal cells maintained in culture Molecular Reproduction and Development 45 291-298

Eyal-Giladi H and Kochav S (1976) From cleavage to primitive streak formation: a complementary normal table and a new look at the first stages of the development of the chick. I. General morphology Developmental Biology 49 321-337

Fraser RA, Carsience RS, Clark ME, Etches RJ and Verrinder Gibbins AM (1993) Efficient incorporation of transfected blastodermal cells into chimeric chicken embryos International journal of Developmental Biology 37 381-385

Hamburger V and Hamilton HL (1951) A series of normal stages in the development of the chick embryo Journal of Morphology 8 49-92

Kopchick JJ, Mills E, Rosenblum C, Taylor J, Macken F, Leung F, Smith J and Chen $\mathrm{H}$ (1991) Methods for the introduction of recombinant DNA into chicken embryos. In Transgenic Animals pp 275-293 Eds N First and FP Haseltine. Butterworth-Heinemann, Boston 
Kuwana T (1993) Migration of avian primordial germ cells toward the gonadal anlage Development, Growth and Differentiation 35 237-243

Li Y, Behnam J and Simkiss K (1995) Ballistic transfection of avian primordial germ cells in ovo. Transgenic Research 4 26-29

Love J, Gribbin C, Mather C and Sang H (1994) Transgenic birds by DNA microinjection Biotechnology 12 60-63

Naito M (1996) Genetic improvement of chickens by direct gene transfer Proceedings of the 20th World's Poultry Congress 1 pp 341-353 New Delhi

Naito M (1997) The microinjection of DNA into early chicken embryo. In Transyenic Animals: Generation and Use pp 69-73 Ed. LM Houdebine. Harwood Academic Publishers, Amsterdam

Naito M, Nirasawa K and Oishi T (1990) Development in culture of the chick embryo from fertilized ovum to hatching Journal of Experimental Zoology $\mathbf{2 5 4}$ 322-326

Naito M, Agata K, Otsuka K, Kino K, Ohta M, Hirose K, Perry MM and Eguchi G (1991) Embryonic expression of $\beta$-actin-lac $Z$ hybrid gene injected into the fertilized ovum of the domestic fowl International Joumal of Developmental Biology 35 69-75

Naito M, Sasaki E, Ohtaki M and Sakurai M (1994a) Introduction of exogenous DNA into somatic and germ cells of chickens by microinjection into the germinal disc of fertilized ova Molecular Reproduction and Development 37 $167-171$

Naito M, Tajima A, Yasuda Y and Kuwana T (1994b) Production of germline chimeric chickens, with high transmission rate of donor-derived gametes, produced by transfer of primordial germ cells Molecular Reproduction and Development 39 153-161

Naito M, Tajima A, Tagami T, Yasuda Y and Kuwana T (1994c) Preservation of chick primordial germ cells in liquid nitrogen and subsequent production of viable offspring Journal of Reproduction and Fertility 102 321-325
Naito M, Tajima A, Yasuda Y and Kuwana T (1998) Donor primordial germ cell-derived offspring from recipient germline chimaeric chickens: absence of long term immune rejection and effects on sex ratios British Poultry Science 39 20-23

Pain B, Clark ME, Shen M, Nakazawa H, Sakurai M, Samarut J and Etches RJ (1996) Long-term in vitro culture and characterisation of avian embryonic cells with multiple morphogenetic potentialities Development $\mathbf{1 2 2}$ 2339-2348

Perry MM (1988) A complete culture system for the chick embryo Nature 331 $70-72$

Perry MM and Sang HM (1993) Transgenesis in chickens Transgenic Research 2 125-133

Rusconi S and Schaffner W (1981) Transformation of frog embryos with a rabbit $\beta$-globin gene Proceedings of the National Academy of Sciences USA 78 5051-5055

Sang HM (1994) Transgenic chickens - methods and potential applications Trends in Biotechnology 12 415-420

Tajima A, Naito M, Yasuda $Y$ and Kuwana T (1993) Production of germ line chimera by transfer of primordial germ cells in the domestic chicken (Gallus domesticus) Theriogenology 40 509-519

Vick L, Li Y and Simkiss K (1993) Transgenic birds from transformed primordial germ cells Proceedings of the Royal Society of London B 251 179-181

Wall RJ (1996) Transgenic livestock: progress and prospects for the future Theriogenology 45 57-68

Watanabe M, Naito M, Sasaki E, Sakurai M, Kuwana T and Oishi T (1994) Liposome-mediated DNA transfer into chicken primordial germ cells in ovo Molecular Reproduction and Development 38 268-274

Yasuda Y, Tajima A, Fujimoto T and Kuwana T (1992) A method to obtain avian germ-line chimeras using isolated primordial germ cells Journal of Reproduction and Fertility $96521-528$ 